\title{
Ex-situ conservation of Cymbidium finlaysonianum by seed storage
}

\author{
DWI MURTI PUSPITANINGTYAS ${ }^{\natural}$, ELIZABETH HANDINI \\ Research Center for Plant Conservation and Botanic Gardens, Indonesian Institute of Sciences. Jl. Ir. H. Juanda 13, Bogor 16122, West Java, Indonesia. \\ Tel./fax.: +62-251-8322187, •email: puspitakrb@gmail.com
}

Manuscript received: 27 February 2020. Revision accepted: 10 July 2020.

\begin{abstract}
Puspitaningtyas DM, Handini E. 2020. Ex-situ conservation of Cymbidium finlaysonianum by seed storage. Biodiversitas 21: 3519-3524. Cymbidium finlaysonianum Lindl. is an orchid that is native to Indonesia which has a pendulous flowers and relatively attractive colors. As a part of the Orchid Seed Storage for Sustainable Use (OSSSU) project, a preliminary study on seed of Cymbidium finlaysonianum Lindl. was conducted to test its viability at Bogor Botanic Gardens, Indonesian Institute of Sciences. The aim of this research was to evaluate the seed viability and to predict the seed longevity of $C$. finlaysonianum, after storage for different periods at freezing temperature $-20^{\circ} \mathrm{C}$. Storing of orchid seeds under cold conditions was the best conventional method in prolonging seed viability. Four different culture media were tested for asymbiotic germination. Seed viability was assessed after the seeds were stored for $0,1,2$, 3, 6, 9, 12 months. Testing continued every year until there was no seed germination, and the viability was lost. The direct method of counting the number of germinating seeds was used to test seed viability. The result showed that seeds of $C$. finlaysonianum were able to germinate in 4 media i.e. Knudson C, modified Knudson C, modified Vacin \& Went, and modified Hyponex fertilizer. The research showed that the viability seeds of $C$. finlaysonianum decreased after 2 years of storage, and the seeds were almost completely non-viable after six years of storage.
\end{abstract}

Keywords: Freezing temperature germination, native orchid, seed longevity, seed viability

\section{INTRODUCTION}

Orchids are ornamental plants that have high commercial value and are most threatened in their natural habitats. Park et al. (2000) said that many Asian orchids are threatened with extinction because of over-collection and habitat destruction. According to Budiharta et al. (2011) biological factors, habitat loss, over-exploitation, and natural factors are the major causes of plant endangerment in Indonesia. For orchids, biological factors and overexploitation for economic purposes are the most important factors that threaten orchids in Indonesia. Compared to other threatened species of Indonesia, orchids species are the most highly threatened species. There are about 203 species (39\% of threatened species of Indonesia) (WCMC 1995).

The long-term challenge for conservation is developing ex situ conservation strategies. Ex-situ techniques are recognized as an important component for conserving all orchids in the world as a complement to in-situ technique (Swarts \& Dixon 2009). Ex-situ methods of conservation consist of the maintenance of species in cultivation and also the storage of pollen and seed. A major opportunity to conserve orchids is storage of their seeds, allowing both preservation and easy distribution of material with a broad genetic base (Pritchard and Seaton 1993). Seed banking has been recognized as being the most efficient way of storing large numbers of living plants in one place (Linington and Pritchard 2001). Orchid seed banking has the potential to make an invaluable contribution to orchid conservation.

Orchid seeds are tiny and do not have an endosperm as a food reserve for germination. They are characterized by a thin balloon-like seed coat. The seeds are light, about
0.341-24 $\mu \mathrm{g}$ and only measuring 0.15-6 mm (Arditti and Ghani 2000; Barthlott et al. 2014). In nature, orchid seeds require penetration by the mycorrhizal fungus to germinate. However, most tropical orchids can germinate in asymbiotic culture medium (Rasmussen et al. 2015). Orchids produce seeds in very large quantities ranging from 376 to $4,000,000$ seeds per fruit and per plant can reach 74,000,000 seeds. Because orchid seeds have a small size and are very light, it is possible to store large amounts of seeds in small volumes. Thus Orchid seed banks may be considered a key strategy for the conservation of valuable genetic resources and the possibility of further reintroduction into natural habitats (Seaton et al. 2010). One of the basic problems in orchid seed banks is the plant regeneration from stored material (Rasmussen et al. 2015).

Orchid seed germination depends mainly on its viability and the media used for germination. To determine the quality of seeds, germination tests are most often used to assess the seed viability in crop production (Hosomi, et al. 2011). Two methods are used for testing seed viability, direct and indirect (Singh 1981). The direct seed viability testing methods involve counting germination of orchid seeds on artificial media and counting the number of seeds that have germinated or have not germinated (Singh 1981; Van Waes and Debergh 1986). While the indirect method is performed by examining the metabolic activity of seeds with the aid of chemicals such as tetrazolium salts or Fluorescein diacetate (Pritchard 1985). Orchid seed germination is marked by the formation of a protocorm. A protocorm is a spherical body that is ready to form shoots and roots at the beginning of germination in seeds that do not have an endosperm. The beginning of orchid seed 
germination is indicated when an embryo has emerged from the testa (Whigham et al. 2006).

Orchid seeds are orthodox, so they need air drying to extend their seed longevity. The viability of seed storage can be prolonged by reducing seed water content, temperature, and oxygen in storage room. Good quality dried orchid seeds have the potential to survive for decades. Reducing water content by up to $5 \%$ and then storing seeds at freezing temperature $\left(-20{ }^{\circ} \mathrm{C}\right)$ has been widely used in orchid seed banks (Seaton \& Pritchard 2011; Seaton et al. 2013). Orchid seeds which are stored under low humidity and low temperature, can survive for decades. On the other hand, they are resistant to sterilizing materials such as sulfuric acid or hypochlorite which used in seed sterilization for in vitro germination (Whigham, et al. 2006). Therefore dry orchid seeds need to be soaked at the outset of germination testing to speed up the absorption of sterile material.

Cymbidium finlaysonianum Lindl. is one of Indonesia's native orchids. Although this species is widely distributed in Southeast Asia, but it is Critically Endangered (CR) in Singapore. Thus $C$. finlaysonianum has been replanted in the wild through the reintroduction programs in Singapore (Yam et al. 2010). In Indonesia, this species has not been evaluated yet for its IUCN Red List category. In order to establish a seed bank, the aim of this research was to evaluate the seed viability and to predict the seed longevity of $C$. finlaysonianum, after storage for different periods at freezing temperature $-20^{\circ} \mathrm{C}$. The viability test of orchid seeds uses the direct method by counting the number of seeds that either germinate or do not germinate directly (Puspitaningtyas and Handini 2014). Different culture media were tested for asymbiotic germination.

\section{MATERIALS AND METHODS}

\section{Sampling materials}

Capsules fruit of Cymbidium finlaysonianum were obtained by manual cross-pollination. After 7-8 months, the fruits were harvested. Only one fruit with thousands of seeds was used as seed lots for germination testing. The fruit of $C$. finlaysonianum is of an oval-spherical shape that is $6-7 \mathrm{~cm}$ long, $\pm 3 \mathrm{~cm}$ in diameter, and a circumference of around 9.5-10 cm. Seeds were removed from the capsule. Seed shape is an elongated oval, 0.8-1 mm in length, and width $\pm 0.2 \mathrm{~mm}$ (Figure 1). Embryos are generally located in the middle of the seed.

\section{Seed viability test}

After seeds were removed from the capsule, seeds were collected on Petri dishes and dried according to the Orchid Seed Storage for Sustainable Use (OSSSU) as recommended by Seaton and Ramsay (2005). Seeds were kept in a desiccator for 5 days to reduce the moisture content of the seeds. Next, the dry seeds were placed in a small airtight bottle, then the small bottles were put in a larger bottle with a silica orange sachet as an indicator inside to ensure that the jar remained airtight. Next, the bottle was given the species name and date of storage. Storage was carried out in the freezer- $20^{\circ} \mathrm{C}$. Then the viability test was carried out after different periods of time (Seaton and Ramsay 2005; Puspitaningtyas and Handini 2014).
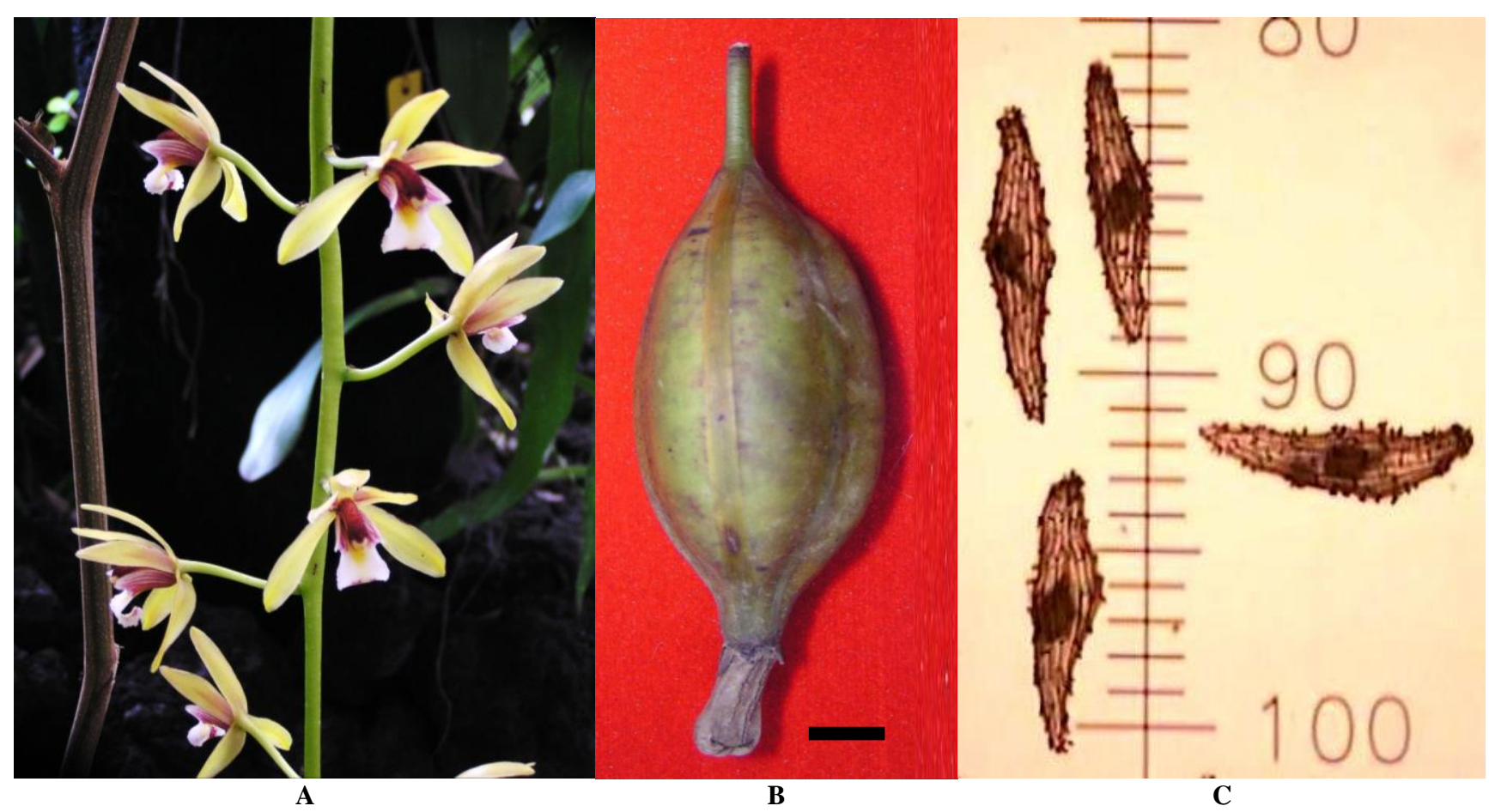

Figure 1. Flowers, fruit and orchid seeds of Cymbidium finlaysonianum: A. Flowers; B. Fruit, Bar =1 cm; C. Seeds magnified 100× 
The seed viability test began with seed sterilization before sowing on the seedling media. Sterilization was done by soaking the seeds sample in a sterile distilled water bottle to which 3 drops of Tween had been added. Then the seeds in sterile distilled water were vacuumed for one hour. The next process was carried out in a laminar air flow hood. The tween solution was removed with a pipette after the seeds had sunk to the bottom of the bottle. Next, the seeds were soaked in $10 \%$ Clorox solution for 10 minutes, followed by soaking in 5\% Clorox solution for 5 minutes. The next step was to rinse with sterile distilled water up to three times. In the third rinse, seeds were sown onto the agar media. Then the sterile distilled water was sucked and removed so that only the seeds were left on the media. The petri dish media were then labeled with the name of the species and the medium as well as the planting date information. After that, the petri dishes were covered with plastic wrap (Puspitaningtyas and Handini 2014).

There were four kinds of media which were used for sowing orchid seed: KCA (pure Knudson $\mathrm{C}$ with the addition of microelements, that are $\mathrm{H} 3 \mathrm{BO} 30.056 \mathrm{mg} / \mathrm{l}$, MoO3 $0.016 \mathrm{mg} / \mathrm{l}$, ZnSO4 $0.331 \mathrm{mg} / \mathrm{l}$, and CuSO4 0.624 $\mathrm{mg} / \mathrm{l}$ (Seaton and Ramsay 2005), KC (Knudson C modification with addition of $1 \mathrm{~g} / \mathrm{l}$ of activated charcoal, extract of bean sprout $150 \mathrm{~g} / \mathrm{l}$ and coconut water $150 \mathrm{ml} / \mathrm{l}$, VW (Vacin and Went modification with addition of active charcoal $1 \mathrm{~g} / \mathrm{l}$, extract of bean sprouts $100 \mathrm{~g} / \mathrm{l}$, extract of tomatoes $100 \mathrm{~g} / \mathrm{l}$ and coconut water $150 \mathrm{ml} / \mathrm{l}$ ), and $\mathrm{HS}$ (Hyponex leaf fertilizer with the addition of activated charcoal $1 \mathrm{~g} / \mathrm{l}$, peptone $2 \mathrm{~g} / \mathrm{l}$ and potatoes $40 \mathrm{~g} / \mathrm{l}$ ) (Puspitaningtyas and Handini 2014).

\section{Data analysis}

Seed sampling was carried out periodically once a year to calculate seed viability. A total of 100-200 seeds were sown on each petri dish. Seeds that began to germinate were observed and counted under a 40× magnification microscope. The percentage of germination was calculated by counting the number of germinated seeds divided by the total seeds sown in one petri dish, then the result was multiplied by $100 \%$. Each type of media was repeated up to three times (Puspitaningtyas and Handini 2014).

\begin{tabular}{ll} 
The percentage of seed & $\begin{array}{c}\text { The number of germinated } \\
\text { germination }(\%)=\end{array}$ \\
\cline { 2 - 2 } & $\begin{array}{c}\text { The total seeds were sown } \\
\text { in one petri dish }\end{array}$
\end{tabular}

The experimental units were set up in a completely randomized design (CRD) with one-factor media. Data were subjected to analysis of variance (ANOVA) using SAS variance analysis version 9.00, and the mean values were separated using Duncan's Multiple Range Test (DMRT) with significance at the 5\% level. Prediction of seed longevity was calculated using regression conducted with Curve Expert 1.3 software on the mean of all seed media.

\section{RESULTS AND DISCUSSION}

\section{Germination test on Different Media}

The results showed that seedlings of $C$. finlaysonianum can germinate on the four media tested. The different media had no effect on germination seed, because the percentage of germination was almost comparable in all four media which can be seen at 0 months (Table 1). The percentage germination decreased gradually within one year of storage. After one year of storage at freezing temperatures of $-20^{\circ} \mathrm{C}$, it showed that the percentage germination of $C$. finlaysonianum was still high (above $80 \%$ ) in 3 media, but on KC media was under $80 \%$ (Table 1). This indicates that storage at low temperatures will extend the viability of orchid seeds. Based on the result, the highest percentage of germination was produced on KCA media and the lowest percentage of germination was showed on $\mathrm{KC}$ media. However, the growth of protocorms on the $\mathrm{KC}$ media produced better protocorms with bigger sizes and more rhizoids compare to KCA media (Figure 2).

It has been shown that media differences affect the quality of growth and development of protocorms. The development of seeds into protocorms produced better growth on media HS, KC, and VW. This was indicated by the good performance of protocorms, that are green, round with plenty of rhizoids (Figure 2). Handini et al. (2016) reported that $\mathrm{VW}$ and $\mathrm{KC}$ media can be used for orchid seed germination, whereas the addition of organic materials in VW medium can support the growth of shoots and roots (Untari and Puspitaningtyas 2006). On media VW, protocorms have more numerous and dense rhizoids than on HS and KC media. This is because the modified VW medium added growth hormone auxin (NAA) 10 ppm, which in its function to stimulate rooting. The addition of auxin (NAA) in the media will encourage the formation of adventitious roots (Setiawati et al. 2018).

The addition of organic material gives a better response to the growth and development of protocorms. The addition of organic materials such as coconut milk, tomatoes, bean sprouts, and potatoes can support the growth of protocorms that are better and faster in terms of the size and number of rhizoids (Kaur and Bhutani 2012; Utami and Hariyanto 2016). Protocorm color for each medium is also slightly different. Visual observation on pure Knudson C (KCA) and Knudson $\mathrm{C}$ modification (KC) produces protocorms with a dark green color, whereas on HS modification medium, the color of the protocorms is a rather pale green. VW modification produced protocorms with a yellowishgreen color (Figure 2). The green color of protocorms is due to the presence of chlorophyll. Chlorophyll is generally derived from iron $(\mathrm{Fe})$, Magnesium $(\mathrm{Mg})$, and Nitrogen (N), so the lack of these elements can cause chlorosis. However in media $\mathrm{VW}, \mathrm{FeSO}_{4} \cdot 7 \mathrm{H}_{2} \mathrm{O}$ is chelated by $\mathrm{Na}_{2}$ EDTA, so the absorption of elemental iron $(\mathrm{Fe})$ by protocorms is inhibited, resulting in chlorotic explants that are pale green.

Protocorm growth on $\mathrm{KC}$ modification is better than on pure Knudson C (KCA) which was shown by the bigger size of protocorms and the number of rhizoids. The 
addition of organic matter coconut water and extract of bean sprouts in the $\mathrm{KC}$ modification was able to increase the growth of protocorms. Coconut water contains the hormone zeatin (a natural form of Cytokinins) (Yong 2009), that support cell division to increase the growth of protocorms and seedlings (Vejsadova 2006, Arditti 2008). In addition, coconut water also contains amino acids, organic acids, nucleic acids, several vitamins, sugar, and sugar alcohol, which improve the quality of plant growth (Shekarriz et al. 2014). The content of coconut water in seed media of as much as $10-30 \%$ can stimulate the growth of Cymbidium finlaysonianum Lindl. protocorms (Tawaro et al. 2008).

HS medium contains only macronutrients such as nitrogen, phosphate, and calcium (25:5:20), but protocorm growth on HS media is relatively good in terms of shape, size, or number of rhizoids. Although HS medium contains the most simple elements, addition of organic materials (peptone) could increase the growth of protocorms. This is in line with Vejsadova's opinion (2006) which states that the addition of peptone can enhance the growth of shoots $43 \%$ better on seedlings of Dactylorhiza maculata subsp. maculata. Peptone can also increase both quality and quantity protocorms' morphogenesis of Paraphalaenopsis serpentilingua (Puspitaningtyas and Dwiarum 2012). This is consistent with the research of Kaur and Bhutani (2012) that peptone $(2 \mathrm{~g} / \mathrm{l})$ and coconut water $(10 \%)$ supplemented medium proved optimum for multiplication of protocormlike bodies (PLBs), maximum number of shoots formation and early plantlet development of Cymbidium pendulum.
Shekarriz et al. (2014) were also found that the addition of coconut water and peptone in media can increase the percentage of germination and number of PLB (Protocorm Like Body) in Phalaenopsis.

While the protocorms growing that showing on $\mathrm{KCA}$ media look smaller than in other media. KCA media do not contain organic materials so that there is less nutrition. However, the KCA media is suitable for germination of Paphiopedilum supardii (Handini et al. 2016). Each orchid species has its own compatibility with the media to germinate.

\section{Viability test and orchid seed longevity of Cymbidium finlaysonianum}

The results showed that storage of $C$. finlaysonianum seeds at freezing temperatures $-20^{\circ} \mathrm{C}$ can retain their viability up to $80 \%$ for one year of storage. After two years of storage, the seed viability decreased by $50-74 \%$. Then within six years of storage, the viability of the seeds decreases rapidly below $1 \%$, and subsequently the seeds had completely lost their viability (Tabel 2). This is also supported by data analysis of regression using Curve Expert 1.3 software to estimate the seed longevity. Based on the analysis data of the viability test for seven years, it showed a negative linear regression (Figure 3 ). The viability of seed storage decreases rapidly as indicated by the percentage of germination. The Seed longevity of Cymbidium finlaysonianum is estimated up to six years storage at freezing temperatures of $-20^{\circ} \mathrm{C}$.

Table 1. Seed germination of Cymbidium finlaysonianum in different media for one-year storage

\begin{tabular}{lccccccc}
\hline \multicolumn{1}{c}{ Media } & $\mathbf{0}$ & $\mathbf{1}$ & $\mathbf{2}$ & $\mathbf{3}$ & $\mathbf{6}$ & $\mathbf{9}$ & $\mathbf{1 2}$ \\
\hline & & & & & & & \\
VW & $96.94 \mathrm{a}$ & $94.62 \mathrm{~b}$ & $93.24 \mathrm{~b}$ & $92.55 \mathrm{~b}$ & $85.65 \mathrm{a}$ & $85.21 \mathrm{a}$ & $83.77 \mathrm{ab}$ \\
KC & $97.67 \mathrm{a}$ & $96.35 \mathrm{ab}$ & $94.43 \mathrm{ab}$ & $92.66 \mathrm{~b}$ & $83.53 \mathrm{a}$ & $79.94 \mathrm{a}$ & $73.68 \mathrm{~b}$ \\
KCA & $98.14 \mathrm{a}$ & $97.51 \mathrm{a}$ & $97.28 \mathrm{a}$ & $96.89 \mathrm{a}$ & $86.38 \mathrm{a}$ & $85.01 \mathrm{a}$ & $84.48 \mathrm{ab}$ \\
HS & $98.68 \mathrm{a}$ & $98.30 \mathrm{a}$ & $97.50 \mathrm{a}$ & $97.07 \mathrm{a}$ & $92.87 \mathrm{a}$ & $92.39 \mathrm{a}$ & $85.30 \mathrm{a}$
\end{tabular}

Note: Numbers followed by the same letter in the same column are not significantly different at the $5 \%$ level $(\mathrm{P} \leq 0.05)$ of the Duncan test

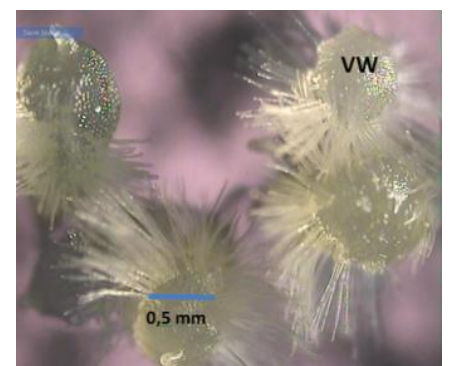

A
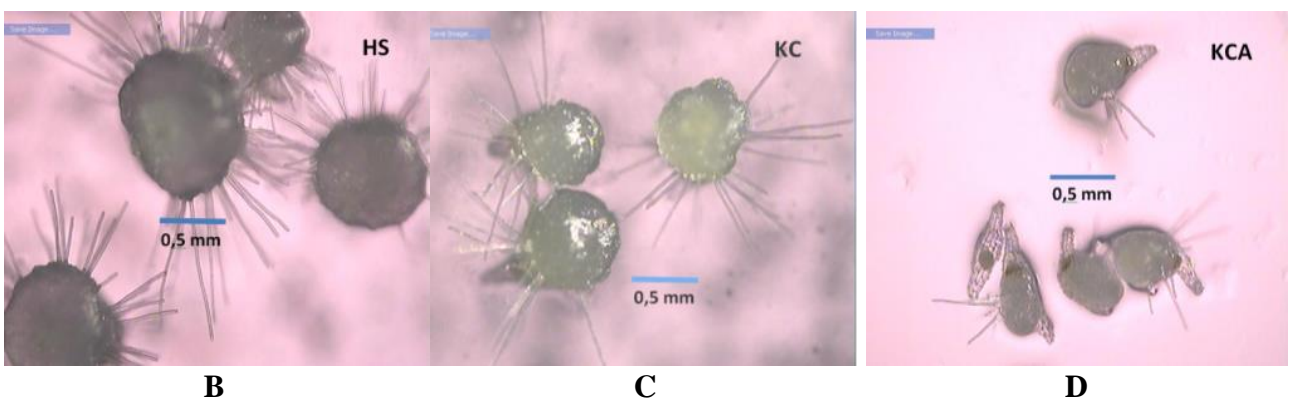

Figure 2. The growth of protocorm on four different media: (A) Vacin and Went (VW) ; (B) Hyponex leaf fertilizer (HS) ; (C) Knudson C (KC); (D) pure Knudson C (KCA). (Bar:0,5 mm) 
Table 2. Seed germination of Cymbidium finlaysonianum in different media for seven years storage

\begin{tabular}{lcccccccc}
\hline \multirow{2}{*}{ Media } & $\mathbf{0}$ & $\mathbf{1}$ & $\mathbf{2}$ & $\mathbf{3}$ & $\mathbf{4}$ & $\mathbf{5}$ & $\mathbf{6}$ & $\mathbf{7}$ \\
\hline VW & $96.94 \mathrm{a}$ & $83.77 \mathrm{ab}$ & $74.03 \mathrm{a}$ & $21.13 \mathrm{~b}$ & $1.95 \mathrm{~b}$ & $0.97 \mathrm{c}$ & $0.98 \mathrm{~b}$ & $0.50 \mathrm{a}$ \\
KC & $97.67 \mathrm{a}$ & $73.68 \mathrm{~b}$ & $61.24 \mathrm{~b}$ & $23.08 \mathrm{~b}$ & $13.59 \mathrm{a}$ & $5.89 \mathrm{a}$ & $0.63 \mathrm{~b}$ & $0.47 \mathrm{a}$ \\
KCA & $98.14 \mathrm{a}$ & $84.48 \mathrm{ab}$ & $50.68 \mathrm{c}$ & $6.67 \mathrm{c}$ & $5.51 \mathrm{~b}$ & $1.63 \mathrm{bc}$ & $0.00 \mathrm{c}$ & $0.00 \mathrm{a}$ \\
HS & $98.68 \mathrm{a}$ & $85.30 \mathrm{a}$ & $66.08 \mathrm{~b}$ & $35.39 \mathrm{a}$ & $19.53 \mathrm{a}$ & $4.42 \mathrm{ab}$ & $1.60 \mathrm{a}$ & $0.46 \mathrm{a}$ \\
\hline
\end{tabular}

Note: Numbers followed by the same letter in the same column are not significantly different at the $5 \%$ level $(\mathrm{P} \leq 0.05)$ of the Duncan test

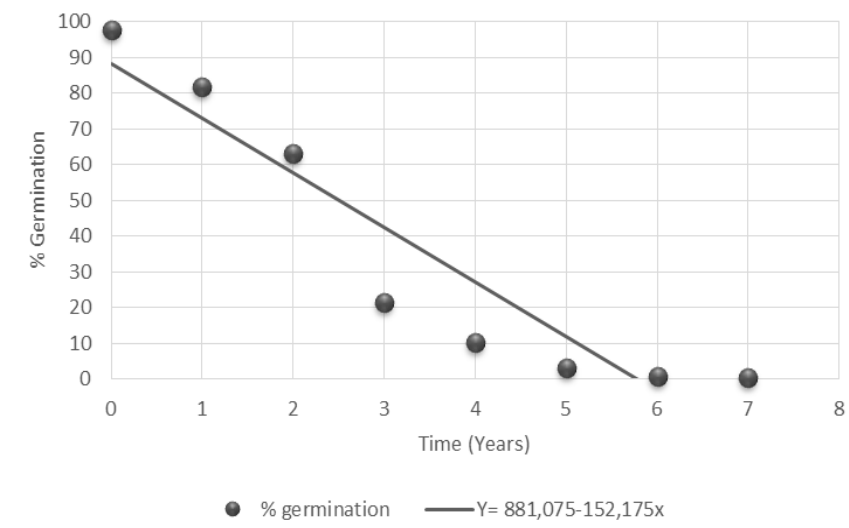

Figure 3. Linear regression of seed longevity of Cymbidium finlaysonianum

The quality of $C$. finlaysonianum seeds was very good as indicated by the initial high percentage of germination. The seeds also show a positive response to freezing temperature storage. After one year of storage the percentage germination of $C$. finlaysonianum was still high (above $80 \%$ ) (Table 1). In contrast, seed of $C$. finlaysonianum can survive only three months if it is stored at room temperature $\left(25-27^{\circ} \mathrm{C}\right)$ (Handini and Puspitaningtyas 2009). Then it was continued by germinating tests every year. Based on that data, the seed viability declines slowly within two years of storage. The time taken for seed viability to fall to $50 \%$ germination was 2.5 years. But after three years storage, the seed lost its viability to below $25 \%$. The seeds were nearly completely non-viable after six years (Table 2; Figure 3$)$. It is proven that storing seeds in low temperature in freezer $\left(-20^{\circ} \mathrm{C}\right)$ can prolong orchid seed viability of $C$. finlaysonianum for up to six years storage (Table 2; Figure 3). According to Alvarez-Pardo and Ferreira (2006) storing seeds at $5^{\circ} \mathrm{C}$ and $-18^{\circ} \mathrm{C}$ in the freezer is the best way to maintain orchid seed viability. In addition, the viability of Dendrobium nobile hybrids seeds stored at $-20^{\circ} \mathrm{C}$ was higher than at room temperature $\left(25+2^{\circ} \mathrm{C}\right)$ as revealed by their germination percentage after 3 months of storage. Then seed germination decreased rapidly after 6 months of storage at room temperature, whereas seeds stored at $-20^{\circ} \mathrm{C}$ the germination decreased after 20 months of storage (Udomdee et al. 2014). Moreover seeds storage at low temperatures $\left(-196^{\circ} \mathrm{C},-18^{\circ} \mathrm{C}\right.$ and $\left.4^{\circ} \mathrm{C}\right)$ can improve the germination of Phalaenopsis and Brassia when compared with storage at room temperature $25^{\circ} \mathrm{C}$, which causes the seeds to lose viability (Mweetwa et al. 2006).

The largest improvement in orchid seed longevity came from the combination of low temperature with dry storage conditions. In addition, storage technique affects the viability of seeds. Viability of $C$. finlaysonianum seeds decreased sharply in just 3 months when stored in a paper envelope. If the seeds are stored in a tightly sealed container, it could prolonged seed viability for up to six months (Handini and Puspitaningtyas 2009).

It has been shown that seeds of $C$. finlaysonianum exhibit orthodox behavior, which has been shown by high viability rates after storage for 2 years. Orthodox seeds are long-lived seeds and can be dried without damage to low moisture contents and are able to tolerate freezing. Dry conditions (low water content) are better than high water content for seed storage. Drying orchid seeds can be done by storing the seeds in a desiccator over silica gel for 4-7 days (Greenspan 1977) or oversaturated solution (Calcium chloride $/ \mathrm{CaCl}_{2}$ or Lithium chloride/LiCl) and left for 3-4 days at room temperature for seed to equilibrate to the required moisture content (Seaton and Ramsay 2005). Pritchard (1984, 1985) mentions that water content is the most principal requirement to maintain the viability of seeds in storage. When the seeds are stored in a freezer with high water content, the high water content will cause the formation of ice crystals that can damage tissue cells. Water content of $3.7 \% ; 5.6 \% ; 6.5 \% ; 10.4 \%$ and $14.1 \%$ at temperature of $5^{\circ} \mathrm{C}$, can maintain the viability orchid seeds of Cattleya aurantiaca for 363 days (Seaton and Hailes 1989). Low water content is the main requirement for the survival of seeds storage. Storing seeds of Dendrobium stratiotes at low water content (10-13\%) show a higher percentage of germination than storing seeds at high water content (18-20\%) (Puspitaningtyas and Handini 2011).

In conclusion, seeds of Cymbidium finlaysonianum were able to germinate in 4 media Knudson C (KCA), modified Knudson C (KC), modified Vacin \& Went (VW) and modified Hyponex fertilizer (HS). However, the growth of seeds into protocorms is better on $\mathrm{HS}, \mathrm{KC}$, and VW. Pure KC (KCA) does not contain organic material so nutrients are lacking. Adding organic material to the media can improve the quality of protocorm growth. Storage of $C$. finlaysonianum orchids in freezing temperatures of $-20^{\circ} \mathrm{C}$ with low water content can extend seed viability by up to six years with optimal viability of only two years. Although the seeds have presented this orthodox behavior, longer storage times should be tested for its maintenance in seed banks. In the future, storing seeds at freezing temperatures- 
$80^{\circ} \mathrm{C}$ is recommended to be tried to prolong seed longevity. Orchid seed banking is a key component of an effective ex situ conservation strategy in the future. Seeds storage is a major opportunity to conserve orchids, allowing both preservation and easy distribution of material with a broad genetic base. By storing orchid seeds, germination testing will produce seedlings, and these seedlings can be used to increase the number of collections and also for research and educational purposes. In addition, seeds and seedlings can be used as a source of plants for reintroduction project to nature.

\section{ACKNOWLEDGEMENTS}

This research is a part of the Orchid Seed Stores for Sustainable Use (OSSSU) project, which aims to store seeds representing at least 1000 orchid species in at least 30 countries in 2016. The author offers sincere thanks to Hugh W. Pritchard, Philip Seaton, and Tim Marks as the management team of the Orchid Seed Stores for Sustainable Use (OSSSU) project, who have funded this research project activity. The author is also grateful to Hugh W. Pritchard and Philip Seaton for giving any suggestions and also his assistance in reading, checking, and translation the manuscripts. DMP is the main author, designed the project, carried out the experiments, and wrote the manuscript with support of EH. EH is co-authors, carried out the experiments, processed the experimental data, and performed the statistical analysis.

\section{REFERENCES}

Alvarez-Pardo V, Ferreira AG. 2006. Orchid seed storage. Revista Brasileira de Sementes 28 (1): 92-98. http://www.scielo.br/scielo.php.

Arditti J, Ghani AKA. 2000. Numerical and physical properties of orchid seeds and their biological implications. New Phytol 145: 367-421.

Arditti J. 2008. Micropropagation of Orchids. Volume 1, 2nd ed Blackwell Publishing Ltd., UK.

Barthlott W, Große-Veldmann B, Korotkova N. 2014. Orchid Seed Diversity: A Scanning Electron Microscopy Survey. Botanic Garden and Botanical Museum Berlin-Dahlem, Berlin.

Budiharta S, Widyatmoko D, Irawati, Wiriadinata H, Rugayah, Partomihardjo T, Ismail, Uji T, Keim AP, Wilson KA. 2011. The processes that threaten Indonesian plants. Oryx 45 (2): 172-179.

Greenspan L. 1977. Humidity fixed points of binary saturated aqueous solutions. J Res Natl Bur Stand 81A: 89-96.

Handini E, Puspitaningtyas DM, Garvita RV. 2016. Conservation of Paphiopedilum supardii Braem \& Loeb by seed storage and in vitro propagation methods. Buletin Kebun Raya 19 (2): 117-127.

Handini E, Puspitaningtyas DM. 2009. Preliminary studies on orchid seeds storage of Cymbidium finlaysonianum. Proceedings of the Conservation of Indonesian Flora in Concerning the Effects of Global Warming, July 14, 2009. Eka Karya Botanic Garden, Bali-LIPI, Bali.

Hosomi ST, Santos RT, Custodio CC, Seaton PT, Marks TR, MachadoNeto NB. 2011. Preconditioning Cattleya seeds to improve the efficacy of the tetrazolium test for viability. Seed Sci Technol 39: 178-189.

Kaur S, Bhutani KK. 2012. Organic growth supplement stimulants for in vitro multiplication of Cymbidium pendulum (Roxb.) Sw. Hort Sci (Prague) 39: (1) 47-52.

Linington SH, Pritchard WH. 2001. Gene banks. in: Levin SA. (eds). Encyclopedia of Biodiversity. Academic Press, New York

Mweetwa A, Tay D, Welbaum G. 2006. Orchid seed storage for germplasm preservation. HortScience 41 (4): 1028.

Park SY, Murthy HN, Paek KY. 2000. In vitro seed germination of Calanthe sieboldii, an endangered orchid species. J Plant Biol 43:158-161.
Pritchard HW. 1984. Liquid nitrogen preservation of terrestrial and epiphytic orchid seed. Cryo-Lett., 5: 295-300.

Pritchard HW. 1985. Determination of orchid seed viability using fluorescein diacetate (Technical Report). Plant Cell Environ 8: 727730 .

Pritchard HW, Seaton PT. 1993. Orchid seed storage: historical perspective, current status, and future prospects for long-term conservation. Selbiyana 14: 89-104.

Puspitaningtyas DM, Dwiarum AC. 2012. Orchid conservation of Paraphalaenopsis serpentilingua by in vitro culture. International Conference on Biological Science. Faculty of Biology Gadjah Mada University, Yogyakarta.

Puspitaningtyas DM, Handini E. 2014. Orchid seeds storage of Coelogyne spp. for ex-situ conservation. Buletin Kebun Raya 17 (2): 101-112.

Puspitaningtyas DM, Handini E. 2011. Orchids seed storage of Dendrobium stratiotes Rchb.f. Proceedings of the National Seminar "Current Conservation and Future Challenges". UPT BKT Kebun Raya Cibodas-LIPI, Cianjur.

Rasmussen HN, Dixon KW, Jersakova J, Tesitelova T. 2015. Germination and seedling establishment in orchids: a complex of requirements. Ann Bot 116: 391-402.

Seaton P, Kendon JP, Pritchard HW, Puspitaningtyas DM, Marks TR. 2013. Orchid conservation: the next ten years. Lankesteriana 13 (1-2): 93-101.

Seaton P, Ramsay M. 2005. Growing Orchids from Seed. Royal Botanic Garden. Kew.

Seaton PT, Hailes NSJ. 1989. Effect of temperature and moisture content on the viability of Cattleya aurantiaca seed. In: Pritchard HW (eds). Modern Methods in Orchid Conservation: The Role of Physiology, Ecology and Management, Cambridge University Press, UK.

Seaton PT, Pritchard WH 2011. Orchid Seed Stores for Sustainable Use: a model for future seed-banking activities. Lankesteriana 11 (3): 349-353.

Seaton PT, Hu H, Perner H, Pritchard HW. 2010. Ex-situ conservation of orchids in a warming world. Bot Rev 76: 193-203.

Setiawati T, Keliat APR, Budiono R, Partasasmita R, Iskandar J. 2018. Influence of NAA and coconut water with variation of soaking duration on the growth of yellow bamboo branch cutting. Nusantara Biosci 10 (3): 178-182.

Shekarriz P, Kafi M, Deilamy SD, Mirmasoumi M. 2014. Coconut water and peptone improve seed germination and protocorm like body formation of hybrid Phalaenopsis. Agric Sci Dev 3 (10): 317-322

Singh F. 1981. Differential staining of orchid seeds for viability testing. Am Orch Soc Bull 50 (4):418-419.

Swarts ND, Dixon KW. 2009. Terrestrial orchid conservation in the age of extinction. Ann Bot 104: 543-556.

Tawaro S, Suraninpong P, Chanprame S. 2008. Germination and regeneration of Cymbidium finlaysonianum Lindl. on a medium supplemented with some organic sources. Walailak J Sci Tech 5 (2): 125-135.

Udomdee W. Wen PJ. Chin SW. Chen FC. 2014. Effect of storage temperature on seed viability and in vitro germination of Nobile Dendrobium Hybrids. Thai Agric Res J 32 (2): 201-217.

Untari R, Puspitaningtyas DM. 2006. The Effect of organic material and levels of NAA concentration on the growth of black orchids (Coelogyne pandurata Lindl.) by in vitro culture. Biodiversitas 7 (4): 378-382.

Utami ESW, Hariyanto S. 2016. The Effect of organic nutrient and growth regulators on seed germination, embryo, and shoots development of Dendrobium antennatum by in vitro. Biosaintifika 8 (2):165-171.

Van Waes JM, Debergh PC. 1986. Adaption of the tetrazolium method for testing the seed viability, and scanning electron microscopy study of some western European orchids. Physiol Plant 66: 435-442.

Vejsadova H. 2006. Factors affecting seed germination and seedling growth of terrestrial orchids cultured in vitro. Acta Biologica Cracoviensia Series Botanica 48 (1): 109-113.

WCMC [World Conservation Monitoring Centre]. 1995. Indonesian threatened plants. Eksplorasi 2 (3): 9.

Whigham DF, O’Neill JP, Rasmunssen HN, Caldwell BA, McCormick MK. 2006. Seed longevity in terrestrial orchids-Potential for persistent in-situ seed banks. Biol Conserv 129: 2-30.

Yam, TW, Chua J, Tay F, Ang P. 2010. Conservation of native orchids through seedling culture and reintroduction-a Singapore experience. Bot Rev 76: 263-274.

Yong JWH, Ge L, Ng YF, Tan SN. 2009. The chemical composition and biological properties of coconut (Cocos nucifera L.) water. Molecules 14 (12): 5144-5164 